\title{
PRINSIP-PRINSIP HUKUM EKONOMI SYARIAH DALAM UNDANG-UNDANG TENTANG PERBANKAN SYARIAH
}

\author{
Muhamad Kholid \\ Fakultas Syari'ah dan Hukum UIN Sunan Gunung Djati Bandung \\ Email : kholid_muhamad@gmail.com
}

\begin{abstract}
Since Law Number 21 of 2008 concerning Sharia Banking was ratified and promulgated on July 16, 2008, the existence of Islamic Banking in Indonesia has a very strong formal juridical basis so that the institutions, business activities and operations of Islamic banking in Indonesia are required to apply sharia principles. This paper aims to explain the principles of sharia economic law which are adopted and become the foundation of the Islamic banking law. The methodology used in this study is to use analytical descriptive method with a normative juridical approach with qualitative analysis. Based on the results of the discussion, the following research is produced, namely that sharia principles in the Sharia Banking Act can be found in Article 1 paragraph (13), (20), (21), (22), (23), (24), (25), and (28); Explanation of Article 3; Article 5 paragraph (4); Article 19 paragraph (1) letters a, b, c, d, e, f, g, and i; Article 19 paragraph (2) letters a, b, c, d, e, f, $\mathrm{g}$, and i; Article 21; consideration of letter (a); and the phrase "With the Grace of God Almighty" at the beginning of the Sharia Banking Act. While the principles of Islamic economic law can be found in Article 1 paragraph (2), (8), (16), (21), (22), (23), (24), (25), (26), ( 27); Section 2; Article 4; Article 19; Article 26; and Article 40 paragraph (1) Sharia Banking Law.
\end{abstract}

\section{Keywords :}

Sharia Economic Law, Sharia Bank

\begin{abstract}
Abstrak
Sejak disahkan dan diundangkan Undang-undang Nomor 21 Tahun 2008 tentang Perbankan Syariah pada tanggal 16 Juli 2008, keberadaan Perbankan syariah di Indonesia memiliki landasan yuridis formal yang sangat kuat sehingga kelembagaan, kegiatan usaha dan operasional perbankan syariah di Indonesia wajib menerapkan prinsip-prinsip syariah. Tulisan ini bertujuan untuk memaparkan prinsip-prinsip hukum ekonomi syariah yang diangkat dan menjadi landasan undang-undang perbankan syariah tersebut. Metodologi yang digunakan dalam penelitian ini adalah menggunakan metode deskriptif analitis dengan pendekatan yuridis normatif dengan analisis kualitatif. Berdasarkan hasil pembahasan maka dihasilkan penelitian sebagai berikut, yaitu bahwa prinsip-prinsip syariah dalam Undang-undang Perbankan Syariah adalah dapat ditemukan pada Pasal 1 ayat (13), (20), (21), (22), (23), (24), (25), dan (28); Penjelasan Pasal 3; Pasal 5 ayat (4); Pasal 19 ayat (1) huruf a, b, c, d, e, f, g, dan i; Pasal 19 ayat (2) huruf a, b, c, d, e, f, g, dan i; Pasal 21; pertimbangan huruf (a); dan frase "Dengan Rahmat Tuhan Yang Maha Esa" di awal Undang-undang Perbankan Syariah. Sedangkan asas-asas hukum ekonomi syariah dapat ditemukan pada Pasal 1 ayat (2), (8), (16), (21), (22), (23), (24), (25), (26), (27); Pasal 2; Pasal 4; Pasal 19; Pasal 26; dan Pasal 40 ayat (1) Undangundang Perbankan Syariah.
\end{abstract}




\section{Kata Kunci: \\ Hukum Ekonomi Syariah, Perbankan Syariah.}

\section{Pendahuluan}

Salah satu tujuan pembentukan dan penegakan hukum Islam adalah dalam rangka memelihara harta ( $h i f d z$ al-mal) agar masing-masing manusia dapat menikmati karunia Allah SWT., yang telah diberikan dari hasil usahanya. Oleh karena itu, Allah SWT., menurunkan Al-Qur'an kepada Nabi Muhammad SAW untuk disampaikan dan ditafsirkan melalui haditsnya. Al-Qur'an dan Al-Hadits tersebut kemudian menjadi sumber ijtihad oleh para mujtahid sebagai usaha untuk menyelesaikan masalah-masalah yang tidak terdapat pengaturannya dalam sumber hukum primer Islam tersebut. Hasilhasil ijtihad para fuqaha tersebut sebagian dikodifikasi sehingga menjadi kumpulan ilmuilmu praktis dalam bentuk fiqih. Di antara ilmu fiqih yang fokus membahas hubungan subyek hukum yang satu dengan subyek hukum yang lain dalam transaksi pengelolaan harta (bisnis) guna memenuhi kebutuhan manusia adalah fiqih muamalah.

Prinsip umum fiqih muamalah adalah kebolehan (al-ibahah), sehingga segala transaksi-transaksi muamalah boleh dilakukan dengan satu syarat yaitu tidak bertentangan dengan syariat Islam. Fiqih muamalah mengatur lebih rinci tentang akadakad yang boleh digunakan dalam transaksi-transaksi bisnis dalam bentuk prinsip-prinsip syariah, seperti mudharabah, bai (murabahah, salam, istishna'), musyarakah, ijarah, hiwalah, kafalah, rahn, qard, dan lain sebagainya.

Di Indonesia, transaksi-transaksi bisnis yang terjadi diwadahi oleh lembaga keuangan, baik perbankan maupun non perbankan. Lembaga keuangan perbankan di Indonesia menggunakan 2 (dua) sistem (dual banking system), yaitu perbankan yang dalam operasional usahanya menggunakan bunga yang sering disebut Bank Konvensional dan perbankan yang dalam menjalankan usahanya menggunakan prinsip-prinsip syariah yang lazim disebut dengan Bank Syariah.

Dari sisi regulasi, keberadaan Bank Syariah memiliki landasan hukum yang sangat kuat sebagaimana diatur dalam Undang-undang Pokok Perbankan (Undangundang Nomor 7 Tahun 1992 yang sudah diubah menjadi Undang-undang Nomor 10 Tahun 1998 tentang Perbankan) dan diatur lebih spesifik dalam Undang-undang Nomor 21 Tahun 2008 tentang Perbankan Syariah. Undang-undang Perbankan Syariah merupakan inisitif DPR RI yang mendapat persetujuan dan pengesahan oleh fraksi-fraksi partai politik beserta pemerintah (Menteri Keuangan dan Menteri Agama) dalam rapat paripurna DPR RI tanggal 17 Juni 2008 yang dihadiri oleh 328 angggota DPR dari jumlah anggota 549 orang kecuali fraksi Partai Damai Sejahtera. Akhirnya, Undang-undang Perbankan Syariah disahkan dan diundangkan di Jakarta pada tanggal 16 Juli 2008. 


\section{Pengertian Hukum Ekonomi Syariah}

CFG. Sunaryati memberikan pengertian hukum ekonomi yaitu keseluruhan kaidah-kaidah, dan putusan-putusan hukum yang secara khusus mengatur kegiatankegiatan ekonomi. Lebih lanjut ia mengungkapkan bahwa pengertian hukum ekonomi adalah keseluruhan asas, kaidah, pranata, dan lembaga baik yang bersifat perdata maupun yang bersifat publik yang mengatur dan mengarahkan tata perekonomian nasional suatu negara. ${ }^{1}$ Fathurrahman Djamil mengartikan hukum ekonomi yaitu keseluruhan kaidah hukum yang mengatur dan memengaruhi segala sesuatu yang berkaitan dengan kegiatan dan kehidupan perekonomian. ${ }^{2}$ Rachmad Soemitro sebagaimana dikutip oleh Abdul Manan mengartikan hukum ekonomi merupakan sebagian dari keseluruhan norma yang dibuat oleh pemerintah atau penguasa sebagai personifikasi dari masyarakat yang mengatur kehidupan kepentingan ekonomi masyarakat yang saling berhadapan. ${ }^{3}$

Terkait pengertian ekonomi syariah, terdapat beberapa pakar ekonomi syariah yang memberikan pendapatnya yaitu sebagai berikut: Muhammad Abdullah Al-Arabi memberikan definisi ekonomi syariah yaitu sekumpulan dasar-dasar umum ekonomi yang disimpulkan dari Al-Qur'an dan Al-Sunnah dan merupakan bangunan perekonomian yang didirikan di atas landasan dasar-dasar tersebut sesuai dengan tiap lingkungan dan masa. ${ }^{4}$

Muhammad Syauqi Al-Fanjari mengartikan ekonomi syariah adalah ilmu yang mengarahkan kegiatan ekonomi dan mengaturnya sesuai dengan dasar-dasar kebijakan (siasat) ekonomi Islam. ${ }^{5}$

M.A. Manan mengartikan ekonomi syariah adalah ilmu pengetahuan sosial yang mempelajari masalah-masalah ekonomi rakyat yang diilhami oleh nilai-nilai Islam. ${ }^{6}$

Kompilasi Hukum Ekonomi Syariah mengartikan ekonomi syariah sebagai suatu atau kegiatan yang dilakukan orang perorang, kelompok orang, badan usaha yang berbadan hukum atau tidak berbadan hukum dalam rangka memenuhi kebutuhan yang bersifat komersial dan tidak komersial menurut prinsip syariah. ${ }^{7}$

Dengan demikian dapat disimpulkan bahwa Hukum Ekonomi Syariah adalah kumpulan prinsip, nilai, asas, dan peraturan terkait kegiatan ekonomi yang dilakukan

${ }^{1}$ CFG Sunaryati Hartono, Hukum Ekonomi Pembangunan Nasional (Bandung : Bina Cipta, 1988), hlm. 53.

${ }^{2}$ Fathurrahman Djamil, Hukum Ekonomi Islam: Sejarah, Teori, dan Konsep, (Jakarta : Sinar Grafika), hlm.53.

${ }^{3}$ Abdul Manan, Aspek Hukum dalam Penyelenggaraan Investasi di Pasar Modal Syariah di Indonesia, (Jakarta : Kencana, 2009), hlm. 6.

${ }^{4}$ Neni Sri Imaniyati, Perbankan Syariah dalam Persfektif Ilmu Ekonomi (Bandung : Mandar Maju. 2013), hlm.18-19.

${ }^{5}$ lbid.

${ }^{6}$ M.A. Manan, Ekonomi Islam: Antara Teori dan Praktik (Jakarta : Intermasa .1992), hlm.19.

${ }^{7}$ Pasal 1 ayat (1) KHES 
oleh antar subjek hukum dalam rangka memenuhi kebutuhan yang bersifat komersial dan tidak komersial berdasarkan Al-Qur'an dan Al-Sunnah.

\section{Prinsip-prinsip Hukum Ekonomi Syariah}

Secara umum, prinsip-prinsip Hukum Ekonomi Syariah/ Hukum Ekonomi Islam adalah sebagai berikut: Prinsip Tauhid, Islam melandaskan kegiatan ekonomi sebagai suatu usaha untuk bekal ibadah kepada Allah SWT., sehingga tujuan usaha bukan semata-mata mencari keuntungan atau kepuasan materi dan kepentingan pribadi melainkan mencari keridhaan Allah SWT., dan kepuasan spiritual dan sosial. Prinsip tauhid dalam usaha sangat esensial sebab prinsip ini mengajarkan kepada manusia agar dalam hubungan kemanusiaan, sama pentingnya dengan hubungan dengan Allah SWT. Islam melandaskan ekonomi sebagai usaha untuk bekal beribadah kepada-Nya.

Prinsip Keadilan, Keadilan adalah suatu prinsip yang sangat penting dalam mekanisme perekonomian Islam. Bersikap adil dalam ekonomi tidak hanya didasarkan pada ayat-ayat Al-Qur'an dan Sunah Nabi tetapi juga berdasarkan pada pertimbangan hukum alam. Alam diciptakan berdasarkan atas prinsip keseimbangan dan keadilan. Adil dalam ekonomi bisa diterapkan dalam penentuan harga, kualitas poduksi, perlakuan terhadap pekerja, dan dampak yang timbul dari berbagai kebijakan ekonomi yang dikeluarkan. Penegakan keadilan dalam rangka menghapus diskriminasi yang telah diatur dalam Al-Qur'an bahkan menjadi satu tujuan utama risalah kenabian yaitu untuk menegakan keadilan.

Prinsip Al-Maslahah, kemaslahatan adalah tujuan pembentukan Hukum Islam yaitu mendapatkan kebahagiaan didunia dan akhirat dengan cara mengambil manfaat dan menolak kemadharatan. Kemaslahatan memiliki 3 sifat, yaitu: (a) Dharuriyyat, adalah sesuatu yang harus ada demi tegaknya kebaikan di dunia dan akhirat dan apabila tidak ada maka kebaikan akan sirna. Sesuatu tersebut terkumpul dalam maqasid alsyari'ah,yaitu memelihara agama, jiwa, keturunan, kekayaan, dan akal. Mencari rizki termasuk pada dharuriyyat karena bertujuan memelihara keturunan dan harta. Pencarian nafkah dapat dilakukan melalui jual beli (murabahah, istisna' dan salam), wadi'ah, musyarakah, ijarah, mudharabah, qardh, wakalah, dll. (b) Hajiyyat, adalah sesuatu yang dibutuhkan masyarakat untuk menghilangkan kesulitan tetapi tidak adanya hajiyyat tidak menyebabkan rusaknya kehidupan. Pada bidang muamalah seperti jual-beli salam, murabahah, istisna'. (c) Tahsiniyyat, adalah mempergunakan sesuatu yang layak dan dibenarkan oleh adat kebiasaan yang baik. Pada bidang muamalah seperti larangan menjual barang najis. Hukum Islam menyempurnakan hajiyyat dengan akhlak yang mulia yang merupakan bagian dari tujuan hukum Islam.

Prinsip Perwakilan (Khalifah), manusia adalah khilafah (wakil) Tuhan di muka bumi. Manusia telah dibekali dengan semua karakteristik mental dan spiritual serta materi untuk memungkinkan hidup dan mengemban misinya secara efektif. Kehidupan manusia senantiasa dibarengi pedoman-pedoman hidup dalam bentuk kitab-kitab suci 
dan shuhuf dari Allah SWT., yang berfungsi untuk mengatur kehidupan manusia guna kebaikannya sendiri selama di dunia maupun di akhirat.

Prinsip AmarMa'ruf Nahy Munkar, Amar Ma'rufyaitu keharusan mempergunakan prinsip Hukum Islam dalam kegiatan usaha sedangkan Prinsip Nahy Munkar direalisasikan dalam bentuk larangan dalam kegiatan usaha yang mengandung unsur riba, gharar, maisyir, dan haram.

Prinsip Tazkiyah, tazkiyah berarti penyucian, dalam konteks pembangunan, proses ini mutlak diperlukan sebelum manusia diserahi tugas sebagai agent of development. Apabila ini dapat terlaksana dengan baik maka apapun pembangunan dan pengembangan yang dilakukan oleh manusia tidak akan berakibat kecuali dengan kebaikan bagi diri sendiri, masyarakat, dan lingkungan.

Prinsip Falah, merupakan konsep tentang kesuksesan manusia. Pada prinsip ini, keberhasilan yang dicapai selama di dunia akan memberikan kontribusi untuk keberhasilan di akhirat kelak selama dalam keberhasilan ini dicapai dengan petunjuk Allah SWT. Oleh karena itu, dalam Islam tidak ada dikotomi antara usaha-usaha untuk pembangunan di dunia (baik ekonomi maupun sektor-sektor lainnya) dengan persiapan untuk kehidupan di akhirat nanti.

Prinsip Kejujuran dan Kebenaran, prinsip ini tercermin dalam setiap transaksi harus tegas, jelas, dan pasti baik barang mapun harga. Transaksi yang merugikan dilarang; Mengutamakan kepentingan sosial. Objek transaksi harus memiliki manfaat. Transaksi tidak mengandung riba, transaksi atas dasar suka sama suka; dan Transaksi tidak ada unsur paksaan.

Prinsip Kebaikan (Ihsan), prinsip ini mengajarkan bahwa dalam ekonomi, setiap muslim diajarkan untuk senantiasa bermanfaat untuk orang banyak, baik seagama, senegara, sebangsa, maupun sesama manusia.

Prinsip Pertanggungjawaban (al-Mas'uliyah), prinsip ini meliputi pertanggungjawaban antara individu dengan individu, pertanggungjawaban dalam masyarakat. Manusia dalam masyarakat diwajibkan melaksanakan kewajibannya demi terciptanya kesejahteraan anggota masyarakat secara keseluruhan, serta tanggungjawab pemerintah, tanggung jawab ini berkaitan dengan pengelolaan keuang negara atau kas negara (bait al-maal) dan kebijakan moneter serta fiskal.

Prinsip Kifayah, prinsip ini terkait kewajiban setiap muslim untuk peduli terhadap sesamanya. Tujuan prinsip ini adalah untuk membasmi kefakiran dan mencukupi kebutuhan primer seluruh anggota masyarakat agar terhindar dari kekufuran.

Prinsip Keseimbangan (wasathiyah/i'tidal), syariat Islam mengakui hak-hak pribadi dengan batas-batas tertentu. Hukum Islam menentukan keseimbangan kepentingan individu dan kepentingan masyarakat. Islam mengakui kepemilikan pribadi dalam batas-batas tertentu termasuk kepemilikan alat produksi dan faktor produksi. 
Menurut Sjaechul Hadi Poernomo sebagaimana dikutip oleh Abd. Shomad, menuturkan terdapat beberapa prinsip-prinsip ekonomi Islam, yaitu: ${ }^{8}$

a. Prinsip Keadilan, prinsip keadilan mencakup seluruh asepk kehidupan, merupakan prinsip yang penting. Sebagaimana Allah SWT., memerintahkan untuk berbuat adil diantara sesama manusia.

b. Prinsip Al-Ihsan, Prinsip Al-ihsan adalah berbuat kebaikan, pemberian manfaat kepaa orang lain lebih dari pad hak orang lain.

c. Prinsip Al-Mas'uliyah, prinsip Al-Mas'uliyah adalah prinsip pertanggungjawaban yang meliputi beragam aspek, yakni pertanggungjawaban antara individu dengan individu (mas'uliyah al-afrad), pertanggungjawaban dalam masyarakat (mas'uliyah al-mujtama).

d. Prinsip Al-Kifayah, prinsip Al-Kifayah adalah kecukupan. Tujuan pokok prinsip ini adalah membasmi kefakiran dan mencukupi kebutuhan primer seluruh anggota dalam masyarakat.

e. Prinsip Wasathiyah/l'tidal, prinsip Wasathiyah adalah prinsip yang mengungkapkan bahwa syariat Islam mengakui hak pribadi dengan batas-batas tertentu. Syariat menentukan keseimbangan antara kepentingan pribadi dengan kepentingan masyarakat.

f. Prinsip Kejujuran dan Kebenaran, prinsip ini merupakan sendi akhlak karimah. Prinsip ini tercermin dalam: (1) Prinsip transaksi yang dilarang, akad transaksi harus tegas, jelas, dan pasti. Baik benda yang menjadi objkakad maupun harga barang yang diakadkan. (2) Prinsip transaksi yang merugikan dilarang. Setiap transaksi yang merugikan diri sendiri maupun pihak kedua dan pihak ketiga dilarang. (3) Prinsip mengutamakan kepentingan sosial. Prinsip ini menekankan pentingnya kepentingan bersamayang harus didahulukan tanpa menyebab kerugian individu. (4) Prinsip manfaat. Objek transaksi harus memiliki manfaat, transaksi terhadap objek yang tidak bermanfaat dilarang menurut syariat. (5) Prinsip transaksi yang mengandung riba dilarang. (6) Prinsip suka sama suka (7) Prinsip tidak ada paksaan.

M. Umar Chafra sebagaimana dikutip oleh Neni Sri Imaniyati, bahwa prinsipprinsip ekonomi Islam, yaitu: ${ }^{9}$

a. Prinsip Tauhid (Keesaan Tuhan), prinsip tauhid dalam ekonomi Islam sangat esensial sebab prinsip ini mengajarkan kepada manusia agar dalam hubungan kemanusiaan (hubungan horizontal), sam pentingnya dengan hubungan dengan Allah SWT., (hubungan vertikal). Dalam arti manusia dalam melakukan aktifitas ekonominya didasarkan pada keadilan sosial yang bersumber pada Al-Qur'an.

\footnotetext{
${ }^{8}$ Mardani, Hukum Sistem Ekonomi Islam, (Jakarta : PT. RajaGafindo Persada. 2015), hlm.18-19.

${ }^{9}$ Ibid., hlm. 19-22
} 
b. Prinsip Khilafah (Perwakilan) manusia adalah khilafah (wakli) Tuhan dimuka buka. Manusia dibekali dengan semua karakteristik mental dan spiritual serta materi untuk memungkinkan hidup dan mengemban misinya secara efektif.

c. Prinsip 'Adalah (Keadilan) keadilan adalah sala satu prinsip yang penting dalam mekanisme perekonomian Islam. Bersikap adil dalam ekonomi tidak hanya didasarkan pada Al-Qur'an dan Sunah Rasul tetapi juga didasarkan pada pertimbangan hukum alam. Alam diciptakan berdasdarkan atas prinsip keseimbangan dan keadilan.

d. Prinsip Tazkiyah (Penyucian)d alam konteks pembangunan, proses ini mutlak diperlukan sebelum manusia diserahi tugas sebagai agent of development. Jikalau proses ini dapat terlaksana secara baik,apapun pembangunan dan pengembangan yang dilakukan oleh manusia tidak akan berakibat kecuali dengan kebaikan bagi diri sendiri, masyarakat, dan lingkungan.

e. Prinsip Al-Falah (Kesuksesan) dalam konsep ini apapun jenisnya keberhasilan yang dicapai selama di dunia akan memberikan kontribusi untuk keberhasilan di akhirat kelak selama dalma keberhasilan ini dicapai dengan petunjuk Allah SWT.

\section{Asas-asas Hukum Ekonomi Syariah}

Pada Hukum Ekonomi Syariah (fiqih muamalah), terdapat beberapa asas yang terdiri dari:

a. Asas Mu'awanah, asas mu'awanah mewajibkan seluruh muslim untuk tolong menolong dan membuat kemitraan dengan melakukan muamalah, yang dimaksud dengan kemitraan adalah suatu startegi bisnis yang dilakukan oleh dua pihak atau lebih dalam jangka waktu tertentu untuk meraih keuntungan bersama dengan prinsip saling membutuhkan dan saling membesarkan.

b. Asas Musyarakah, asas musyarakah menghendaki bahwa setiap bentuk muamalah kerjasama antar pihak yang saling menguntungkan bukan saja bagi pihak yang terlibat melainkan bagi keseluruhan masyarakat, oleh karena itu ada harta yang dalam muamalat diperlakukan sebagai milik bersama dan sama sekali tidak dibenarkan dimiliki perorangan.

c. Asas Manfaah (tabadulul manafi'), asas manfaah berarti bahwa segala bentuk kegiatan muamalat harus memberikan keuntungan dan manfaat bagi pihak yang terlibat, asas ini merupakan kelanjutan dari prinsip atta'awun (tolong menolong /gotong royong) atau mu'awanah (saling percaya) sehingga asas ini bertujuan menciptakan kerjasama antar individu atau pihak-pihak dalam masyarakat dalam rangka saling memenuhi keperluannya masing-masing dalam rangka kesejahteraan bersama. Asas manfaah adalah kelanjutan dari prinsip pemilikan dalam hukum Islam yang menyatakan bahwa segala yang dilangit dan di bumi pada hakikatnya adalah milik Allah SWT, dengan demikian manusia bukanlah 
pemilik yang berhak sepenuhnya atas harta yang ada di bumi ini, melainkan hanya sebagai pemilik hak memanfaatkannya.

d. Asas Antarodhin, asas antaradhin atau suka sama suka menyatakan bahwa setiap bentuk muamalat antar individu atau antar pihak harus berdasarkan kerelaan masing-masing, Kerelaan disini dapat berarti kerelaan melakukan suatu bentuk muamalat, maupun kerelaan dalam arti kerelaan dalam menerima dan atau menyerahkan harta yag dijadikan obyek perikatan dan bentuk muamalat lainnya.

e. Asas 'Adamul Gharar, Asas 'adamul gharar berarti bahwa pada setiap bentuk muamalat tidak boleh ada gharar atau tipu daya atau sesuatu yang menyebabkan salah satu pihak merasa dirugikan oleh pihak lainnya sehingga mengakibatkan hilangnya unsur kerelaan salah satu pihak dalam melakukan suatu transaksi.

b. Al Musawah, asas ini memiliki makna kesetaraan atau kesamaan, artinya bahwa setiap pihak pelaku muamalah berkedudukan sama.

c. Ash shiddiq, dalam Islam, manusia diperintahkan untuk menjunjung kejujuran dan kebenaran, jika dalam bermuamalah kejujuran dan kebenaran tidak dikedepankan, maka akan berpengaruh terhadap keabsahan perjanjian. Perjanjan yang didalamnya terdapat unsur kebohongan menjadi batal atau tidak sah.

d. Asas Hak Milik, Islam mengakui hak milik perorangan. Oleh karena itu Islam mewajibkan kepada umatnya untuk selalu berusaha. Dengan kepemilikan harta maka seorang muslim bisa membantu saudaranya yang lain dan memberikan hak orang lain yang ada pada hartanya sehingga dengan hartanya seorang muslim bisa mendapatkan kebahagiaan diakhirat kelak.

e. Asas Pemerataan, asas pemerataan adalah penerapan prinsip keadilan dalam bidang muamalah yang bertujuan agar harta tidak hanya dikuasai oleh segelintir orang saja, tetapi harus didistribusikan secara merata di antara masyarakat, baik kaya maupun miskin, dengan dasar tujuan ini maka dibuatlah hukum zakat, shadaqah, infaq.

f. Asas al-Bir wa al-Taqwa, Al-bir artinya kebajikan dan berimbang atau proporsional maksudnya keadilan atau perilaku yang baik. Sedangkan al-taqwa berarti takut, hati-hati, jalan lurus, dan meninggalkan yang tidak berguna, melindungi dan menjaga diri dari murka Allah SWT. Asas ini yang mewadahi seluruh asas fiqih muamalah. Artinya segala asas dalam lingkup fiqih muamalah dilandasi dan diarahkan untuk Al-Bir wa al-Taqwa. Hal-hal yang harus dihindari dalam bermuamalah adalah Maisir, Gharar, Haram, Riba dan Bathil.

Maisir, Maisir sering dikenal dengan perjudian, dalam praktik perjudian seseorang bisa untung dan bisa rugi. Gharar setiap transaksi yang masih belum jelas barangnya atau tidak berada dalam kuasanya alias diluar jangkauan termasuk jual beli gharar, boleh dikatakan bahwa konsep gharar berkisar kepada makna 
ketidakjelasan suatu transaksi dilaksanakan. Haram, Ketika obyek yang diperjualbelikan ini haram, maka transaksinya menjadi tidak sah. Riba, Riba adalah penambahan pendapatan secara tidak sah, antara lain dalam transaksi pertukaran barang sejenis yang tidak sama kualitas, kuantitas dan waktu penyerahan. Bathil, dalam melakukan transaksi, prinsip yang harus dijunjung adalah tidak ada kedzaliman yang dirasa pihak-pihak yang terlibat, semuanya harus sama-sama rela dan adil sesuai takarannya. maka, dari sisi ini transaksi yang terjadi akan merekatkan ukhuwah pihak-pihak yang terlibat. Kecurangan, ketidakjujuran, menutupi cacat barang, mengurang timbangan tidak dibenarkan, atau hal-hal kecil seperti penggunaan barang tanpa izin.

\section{Metodologi Penelitian}

Metode yang digunakan pada penelitian ini adalah deskriptif analitis, yaitu mengumpulkan data yang menggambarkan atau memaparkan apa adanya dari hasil penelitian kemudian disusun dan dituangkan dalam bentuk tulisan (naratif), ditafsirkan dan dianalisis. Penelitian ini bertujuan untuk mendapat gambaran tentang suatu keadaan secara objektif dalam situasi secara lengkap dan terperinci mengenai kumpulan pengaturan mengenai perbankan syariah di Indonesia.

Pendekatan yang akan digunakan dalam penelitian ini adalah penelitian yuridis normatif yaitu penelitian yang mencakup penelitian suatu asas-asas hukum, sistematika hukum, singkronisasi hukum vertikal dan horizontal. ${ }^{10}$ Kaitannya dengan penelitian ini, peneliti melakukan penelaahan secara mendalam terhadap peraturan perundangundangan yang berkaitan dengan perbankan syariah.

Penelitian ini menggunakan Penelitian Kepustakaan (Library Research) yaitu penelitian terhadap data sekunder. Pengumpulan data dalam penelitian ini diperoleh melalui penelusuran peraturan perundang-undangan perbankan, dokumen, maupun literatur ilmiah dan penelitian para pakar yang sesuai serta berkaitan dengan objek penelitian termasuk permasalahan yang akan diteliti dan diperoleh dari data sekunder. ${ }^{11}$

Adapun teknik pengumpulan data yang digunakan dalam penelitian ini adalah menggunakan penelaahan kepustakaan untuk mempelajari dan mengumpulkan data dan informasi dari literatur yang ada hubungannya dengan penelitian ini termasuk bahan hukum primer, sekunder dan tersier. Pada penelitian ini dilakukan penelaahan terhadap Undang-undang Perbankan Syariah secara langsung kemudian dihubungkan dengan teori-teori yang ada dalam literatur-literatur tentang Hukum Ekonomi Syariah.

Analisis yang dipergunakan dalam penelitian ini adalah Kualitatif. Analisis ini maksudnya data yang diperoleh disajikan secara deskriptif dalam bentuk kalimat yang

\footnotetext{
${ }^{10}$ Soerjono Soekanto dan Sri Mamudji, Penelitian Hukum Normatif suatu tinjauan singkat, (Jakarta : Rajawali Pers), 1985, hlm. 37

${ }^{11}$ Ronny Hanitijo Soemitro, Metodologi Penelitian Hukum dan Jurimetri (Jakarta : Ghalia Indonesia : Jakarta. 1994), hlm.97.
} 
benar, lengkap, sistematis, sehingga tidak menimbulkan penafsiran yang beragam dan kemudian disajikan sebagai dasar dalam menarik suatu kesimpulan. ${ }^{12}$ Penelaahan terhadap Undang-undang Perbankan Syariah secara langsung kemudian dilakukan analisis terhadap substansinya dengan menggunakan prinsip-prinsip dan asas-asas syariah dalam Hukum Ekonomi Syariah.

\section{Pembahasan}

\section{Penerapan Prinsip Syariah dalam Undang-undang Perbankan Syariah}

Prinsip-prinsip syariah yang diangkat dalam Undang-undang Perbankan Syariah adalah sebagai berikut:

\section{Prinsip Al-Maslahah}

Kemaslahatan adalah tujuan pembentukan Hukum Islam yaitu mendapatkan kebahagiaan di dunia dan akhirat dengan cara mengambil manfaat dan menolak kemadharatan. UU Perbankan Syariah berorientasi pada pengembangan ekonomi berdasarkan nilai-nilai Islam yaitu keadilan, kemanfaatan, keseimbangan, dan keuniversalitasan sehingga masyarakat Indonesia dimasa depan akan mengalami peningkatan kesejahteraan ekonomi di atas landasan prinsip syariah. Hal ini dapat dilihat dalam tujuan Perbankan Syariah adalah: Perbankan Syariah bertujuan menunjang pelaksanaan pembangunan nasional dalam rangka meningkatkan keadilan, kebersamaan, dan pemerataan kesejahteraan rakyat. ${ }^{13}$

Kemaslahatan memiliki 3 sifat, yaitu:

Dharuriyyat, sesuatu yang harus ada demi tegaknya kebaikan di dunia dan akhirat dan apabila tidak ada maka kebaikan akan sirna. Sesuatu tersebut terkumpul dalam maqasid al-syari'ah, yaitu memelihara agama, jiwa, keturunan, kekayaan, dan akal. Mencari rizki termasuk pada dharuriyyat karena bertujuan memelihara keturunan dan harta. Pencarian nafkah dapat dilakukan melalui jual beli (murabahah, istisna'dan salam), wadi'ah, musyarakah, ijarah, mudharabah, qardh, wakalah, dan lain-lain. Perbankan syariah dalam kegiatan usahanya berpedoman pada prinsip-prinsip tersebut.

Pertama, ${ }^{14}$ Pasal 1 ayat (20-25) dan ayat (28), yang berbunyi sebagai berikut: Simpanan adalah dana yang dipercayakan oleh Nasabah kepada Bank Syariah dan/atau UUS berdasarkan Akad wadi'ah atau Akad lain yang tidak bertentangan dengan Prinsip Syariah dalam bentuk Giro, Tabungan, atau bentuk lainnya yang dipersamakan dengan itu. Tabungan adalah Simpanan berdasarkan Akad wadi'ah atau Investasi dana berdasarkan Akad mudharabah atau Akad lain yang tidak bertentangan dengan Prinsip Syariah yang penarikannya hanya dapat dilakukan menurut syarat dan ketentuan tertentu yang disepakati, tetapi tidak dapat ditarik dengan cek, bilyet giro, dan/atau alat lainnya yang

\footnotetext{
${ }^{12}$ Soejono Soekanto, Pengantar Penelitian Hukum, (Jakarta : Universitas Indonesia. 1986), hlm. 68

${ }^{13}$ Pasal 3 UU Perbankan Syariah.

${ }^{14}$ Atang Abd. Hakim, Fiqih Perbankan Syariah: Transformasi Fiqih Muamalah Ke dalam Peraturan Perundang-undangan (Bandung : Refika Aditama. 2011) , hlm. 144-145.
} 
dipersamakan dengan itu. Deposito adalah Investasi dana berdasarkan Akad mudharabah atau Akad lain yang tidak bertentangan dengan Prinsip Syariah yang penarikannya hanya dapat dilakukan pada waktu tertentu berdasarkan Akad antara Nasabah Penyimpan dan Bank Syariah dan/atau UUS. Giro adalah Simpanan berdasarkan Akad wadi'ah atau Akad lain yang tidak bertentangan dengan Prinsip Syariah yang penarikannya dapat dilakukan setiap saat dengan menggunakan cek, bilyet giro, sarana perintah pembayaran lainnya, atau dengan perintah pemindahbukuan. Investasi adalah dana yang dipercayakan oleh Nasabah kepada Bank Syariah dan/atau UUS berdasarkan Akad mudharabah atau Akad lain yang tidak bertentangan dengan Prinsip Syariah dalam bentuk Deposito, Tabungan, atau bentuk lainnya yang dipersamakan dengan itu.

Pembiayaan adalah penyediaan dana atau tagihan yang dipersamakan dengan itu berupa: (1) transaksi bagi hasil dalam bentuk mudharabah dan musyarakah; (2) transaksi sewa-menyewa dalam bentuk ijarah atau sewa beli dalam bentuk ijarah muntahiya bittamlik; (3) transaksi jual beli dalam bentuk piutang murabahah, salam, dan istishna'; (4) transaksi pinjam meminjam dalam bentuk piutang qardh; dan (5) transaksi sewa-menyewa jasa dalam bentuk ijarah untuk transaksi multijasa berdasarkan persetujuan atau kesepakatan antara Bank Syariah dan/atau UUS dan pihak lain yang mewajibkan pihak yang dibiayai dan/atau diberi fasilitas dana untuk mengembalikan dana tersebut setelah jangka waktu tertentu dengan imbalan ujrah, tanpa imbalan, atau bagi hasil.

Wali Amanat adalah Bank Umum Syariah yang mewakili kepentingan pemegang surat berharga berdasarkan Akad wakalah antara Bank Umum Syariah yang bersangkutan dan pemegang surat berharga tersebut.

Kedua, Pasal 19 ayat (1) huruf a-g, dan i, yang berbunyi : Kegiatan usaha Bank Umum Syariah meliputi:

a. Menghimpun dana dalam bentuk Simpanan berupa Giro, Tabungan, atau bentuk lainnya yang dipersamakan dengan itu berdasarkan Akad wadi'ah atau Akad lain yang tidak bertentangan dengan Prinsip Syariah;

b. Menghimpun dana dalam bentuk Investasi berupa Deposito, Tabungan, atau bentuk lainnya yang dipersamakan dengan itu berdasarkan Akad mudharabah atau Akad lain yang tidak bertentangan dengan Prinsip Syariah;

c. Menyalurkan Pembiayaan bagi hasil berdasarkan Akad mudharabah, Akad musyarakah, atau Akad lain yang tidak bertentangan dengan Prinsip Syariah;

d. Menyalurkan Pembiayaan berdasarkan Akad murabahah, Akad salam, Akad istishna', atau Akad lain yang tidak bertentangan dengan Prinsip Syariah;

e. Menyalurkan Pembiayaan berdasarkan Akad qardh atau Akad lain yang tidak bertentangan dengan Prinsip Syariah; 
f. Menyalurkan Pembiayaan penyewaan barang bergerak atau tidak bergerak kepada Nasabah berdasarkan Akad ijarah dan/atau sewa beli dalam bentuk ijarah muntahiya bittamlik atau Akad lain yang tidak bertentangan dengan Prinsip Syariah;

g. Melakukan pengambilalihan utang berdasarkan Akad hawalah atau Akad lain yang tidak bertentangan dengan Prinsip Syariah;

h. Membeli, menjual, atau menjamin atas risiko sendiri surat berharga pihak ketiga yang diterbitkan atas dasar transaksi nyata berdasarkan Prinsip Syariah, antara lain, seperti Akad ijarah, musyarakah, mudharabah, murabahah, kafalah, atau hawalah;

i. Melakukan fungsi sebagai Wali Amanat berdasarkan Akad wakalah; Ketiga, Pasal 19 ayat (2) huruf a-g, dan i, yang berbunyi : Kegiatan usaha UUS meliputi:

a. Menghimpun dana dalam bentuk Simpanan berupa Giro, Tabungan, atau bentuk lainnya yang dipersamakan dengan itu berdasarkan Akad wadi'ah atau Akad lain yang tidak bertentangan dengan Prinsip Syariah;

b. Menghimpun dana dalam bentuk Investasi berupa Deposito, Tabungan, atau bentuk lainnya yang dipersamakan dengan itu berdasarkan Akad mudharabah atau Akad lain yang tidak bertentangan dengan Prinsip Syariah;

c. Menyalurkan Pembiayaan bagi hasil berdasarkan Akad mudharabah, Akad musyarakah, atau Akad lain yang tidak bertentangan dengan Prinsip Syariah;

d. Menyalurkan Pembiayaan berdasarkan Akad murabahah, Akad salam, Akad istishna', atau Akad lain yang tidak bertentangan dengan Prinsip Syariah;

e. Menyalurkan Pembiayaan berdasarkan Akad qardh atau Akad lain yang tidak bertentangan dengan Prinsip Syariah;

f. Menyalurkan Pembiayaan penyewaan barang bergerak atau tidak bergerak kepada Nasabah berdasarkan Akad ijarah dan/atau sewa beli dalam bentuk ijarah muntahiya bittamlik atau Akad lain yang tidak bertentangan dengan Prinsip Syariah;

g. Melakukan pengambilalihan utang berdasarkan Akad hawalah atau Akad lain yang tidak bertentangan dengan Prinsip Syariah;

h. Membeli dan menjual surat berharga pihak ketiga yang diterbitkan atas dasar transaksi nyata berdasarkan Prinsip Syariah, antara lain, seperti Akad ijarah, musyarakah, mudharabah, murabahah, kafalah, atau hawalah.

Keempat, Pasal 21, yang berbunyi : Kegiatan usaha Bank Pembiayaan Rakyat Syariah meliputi: (1) Menghimpun dana dari masyarakat dalam bentuk: a) Simpanan berupa Tabungan atau yang dipersamakan dengan itu berdasarkan Akad wadi'ah atau Akad lain yang tidak bertentangan dengan Prinsip Syariah; dan b) Investasi berupa Deposito atau Tabungan atau bentuk lainnya yang dipersamakan dengan itu berdasar- 
kan Akad mudharabah atau Akad lain yang tidak bertentangan dengan Prinsip Syariah. (2) Menyalurkan dana kepada masyarakat dalam bentuk: a) Pembiayaan bagi hasil berdasarkan Akad mudharabah atau musyarakah, a) Pembiayaan berdasarkan Akad murabahah, salam, atau istishna', c) Pembiayaan berdasarkan Akad qardh, d) Pembiayaan penyewaan barang bergerak atau tidak bergerak kepada asabah berdasarkan Akad ijarah atau sewa beli dalam bentuk ijarah muntahiya bittamlik; dan e) pengambilalihan utang berdasarkan Akad hawalah. (3) Menempatkan dana pada Bank Syariah lain dalam bentuk titipan berdasarkan Akad wadi'ah atau Investasi berdasarkan Akad mudharabah dan/atau Akad lain yang tidak bertentangan dengan Prinsip Syariah.

Hajiyyat, merupakan sesuatu yang dibutuhkan masyarakat untuk menghilangkan kesulitan tetapi tidak adanya hajiyyat tidak menyebabkan rusaknya kehidupan. Pada bidang muamalah seperti jual-beli salam, murabahah, istisna'. Perwujudan hajiyyat dalam perbankan syariah bertujuan untuk memelihara keturunan dan harta. Keturunan akan terhindar memakan makanan yang haram dan terhindar dari rizki yang dilarang syariat. Hajiyyat dapat dilihat pada Pasal 1 ayat (13) UU Perbankan Syariah tentang definisi akad. "Akad adalah kesepakatan tertulis antara Bank Syariah atau UUS dan pihak lain yang memuat adanya hak dan kewajiban bagi masing-masing pihak sesuai dengan Prinsip Syariah."

Tahsiniyyat, adalah mempergunakan sesuatu yang layak dan dibenarkan oleh adat kebiasaan yang baik. Pada bidang muamalah seperti larangan menjual barang najis. Hukum Islam menyempurnakan hajiyyat dengan akhlak yang mulia yang merupakan bagian dari tujuan hukum Islam.

\section{Prinsip Tauhid}

Islam melandaskan kegiatan ekonomi sebagai suatu usaha untuk bekal ibadah kepada Allah SWT, sehingga tujuan usaha bukan semata-mata mencari keuntungan atau kepuasan materi dan kepentingan pribadi melainkan mencari keridhaan Allah SWT., dan kepuasan spiritual dan sosial. Aplikasi Prinsip Tauhid dalam UU Perbankan Syariah, yaitu: (1) UU Perbankan Syariah diawali dengan frase "Dengan Rahmat Tuhan Yang Maha Esa". "Rahmat" merupakan faktor untuk meraih kebahagiaan dan keselamatan hidup manusia di dunia dan akhirat. Oleh karena itu, "Rahmat" diartikan nikmat dan pertolongan serta ampunan dan karunia. Dengan demikian, UU Perbankan Syariah merupakan wujud dari rahmat Allah SWT. (2) Penjelasan Pasal 3 UU Perbankan Syariah. Bahwa dalam menunjang pelaksanaan pembangunan nasional, perbankan syariah tetap berpegang teguh pada prinsip syariah secara menyeluruh (kaffah) dan konsisten (istigomah). (3) Pasal 5 ayat (4) UU Perbankan Syariah. Bank Konvensional yag akan menjadi Bank Syariah/ UUS yang telah mendapat izin usaha wajib mencantumkan dengan jelas kata "syariah" pada penulisan nama banknya. Kata "syariah" mengisyarat- 
158 | Asy-Syari'ah Vol. 20 No. 2, Desember 2018

kan nilai tauhid karena operasional perbankan syariah dikembalikan pada prinsip Islam yang diciptakan Allah YME.

\section{Prinsip Keadilan}

Prinsip Keadilan, aplikasi Prinsip Keadilan dalam UU Perbankan Syariah, yaitu: (1) Pertimbangan huruf (a), yang berbunyi: Bahwa sejalan dengan tujuan pembangunan nasional Indonesia untuk mencapai terciptanya masyarakat adil dan makmur berdasarkan demokrasi ekonomi, dikembangkan sistem ekonomi yang berlandaskan pada nilai keadilan, kebersamaan, pemerataan, dan kemanfaatan yang sesuai dengan prinsip syariah. (2) Nilai keadilan dalam kegiatan usaha Perbankan Syariah adalah tergambar dari beragamnya akad yang dipergunakan sebagai upaya penyesuaian berdasarkan kebutuhan secara proporsional.

\section{Prinsip Amar Ma'ruf Nahy Munkar}

Prinsip Amar Ma'ruf dalam UU Perbankan Syariah, yaitu keharusan mempergunakan prinsip Hukum Islam dalam kegiatan usaha Perbankan Syariah sedangkan Prinsip Nahy Munkar direalisasikan dalam bentuk larangan dalam kegiatan usaha yang mengandung unsur riba, gharar, maisyir, dan haram.

\section{Asas-asas Hukum Ekonomi Syariah dalam Undang-undang Perbankan Syariah}

Asas-asas Hukum Ekonomi Syariah dalam Undang-undang Perbankan Syariah adalah sebagai berikut: ${ }^{15}$

Asas Pertukaran Manfaat, Kerjasama, Hak Milik, Tolong Menolong

Pertukaran manfaat mengandung pengertian keterlibatan orang banyak, baik secara individu maupun lembaga. Oleh karena itu dalam pertukaran manfaat terkandung norma kerja sama (musyarakah). Pertukaran manfaat juga terkait hak milik seseorang karena perputaran manfaat hanya dapat terjadi dalam benda yang dimiliki. Proses pertukaran manfaat melalui norma kerja sama (musyarakah) dan norma hak milik (haq milk) berakhir dinorma tolong menolong (al-ta'awun). Dalam Islam, tolong menolong hanya terjadi dalam kebaikan dan ketaqwaan serta dalam hal yang membawa manfaat bagi semua.

Aplikasi asas-asas di atas dalam UU Perbankan Syariah, adalah Pasal 4 UU Perbankan Syariah, yang berbunyi sebagai berikut: (1) Bank Syariah dan UUS wajib menjalankan fungsi menghimpun dan menyalurkan dana masyarakat. (2) Bank Syariah dan UUS dapat menjalankan fungsi sosial dalam bentuk lembaga baitul mal, yaitu menerima dana yang berasal dari zakat, infak, sedekah, hibah, atau dana sosial lainnya dan menyalurkannya kepada organisasi pengelola zakat. (3) Bank Syariah dan UUS dapat

\footnotetext{
${ }^{15}$ Ibid.
} 
menghimpun dana sosial yang berasal dari wakaf uang dan menyalurkannya kepada pengelola wakaf (nazhir) sesuai dengan kehendak pemberi wakaf (wakif).

Perbankan Syariah bukan hanya berfungsi sebagai lembaga penghimpun dan menyalur dana semata melainkan juga berfungsi sosial dengan menerima dana zakat, infaq, dan shadaqah, hibah, wakaf. Pasal 4 bertalian dengan Pasal 1 ayat (2) tentang menghimpun dan menyalurkan dana, (8) tentang pemberian jasa dalam lalu lintas pembayaran, (16) tentang nasabah yang menggunakan jasa bank syariah, (26) tentang agunan, (27) tentang penitipan barang; Pasal 19 huruf a, b, c, d tentang kegiatan usaha perbankan syariah. Pertukaran Manfaat, Kerjasama, Hak Milik, Tolong Menolong untuk menyelesaikan masalah-masalah sosial seperti kemiskinan, penimbunan harta, dan individualisme.

\section{Asas Pemerataan, 'an Taradhin, 'adam Al-Gharar,dan al-Bir wa al-Taqwa}

Pertama, asas pemerataan merupakan menempatkan manusia sebagai makhluk yang memiliki kesempatan yang sama untuk memiliki, mengelola, dan menikmati sumber daya ekonomi sesuai dengan kemampuannya. Perbedaan agama, suku, jenis kelamin, dan tempat tinggal tidak menghilangkan hak dan kewajiban mereka bermuamalah antara sesamanya. Aplikasi asas pemerataan dalam UU Perbankan Syariah adalah: a) Pasal 2 yaitu Perbankan Syariah dalam melakukan kegiatan usahanya berasaskan Prinsip Syariah, demokrasi ekonomi, dan prinsip kehati-hatian. Pada asas demokrasi ekonomi terkandung nilai pemerataan karena demokrasi ekonomi berarti kegiatan ekonomi syariah mengandung nilai keadilan, kebersamaan, pemerataan, dan kemanfaatan, b) Pasal 4 tentang fungsi Perbankan Syariah yang bukan hanya menjalankan fungsi perbankan semata tetapi ditambah dengan fungsi sosial.

Kedua, asas 'an Taradhin berarti saling merelakan atau suka sama suka. Rela dalam bermuamalah atau kerelaan dalam menyerahkan dan menerima harta yang menjadi objek akad. Aplikasi asas 'an Taradhin dalam UU Perbankan Syariah adalah: a) Pasal 1 ayat (21-25) tentang definisi tabungan, deposito, giro, investasi, dan pembiayaan, b) Pasal 40 ayat (1) tentang kebolehan BUS atau UUS membeli seluruh atau sebagian agunan nasabah.

Ketiga, asas 'adam Al-Gharar, artinya prilaku saling merelakan memungkinkan tertutupnya sifat-sifat gharar dalam berbagai bentuk transaksi muamalah. Al-Gharar adalah sesuatu yang tidak diketahui atau tidak jelas. Pada Al-Gharar terdapat unsur spekulasi bahkan penipuan yang dapat menghilangkan 'an Taradhin. Aplikasi asas 'adam Al-Gharar dalam UU Perbankan Syariah adalah adanya prinsip kehati-hatian, izin usaha dan perizinan pembukaan kantor cabang, pengambilalihan utang, kelayakan penyaluran dana, larangan bagi Bank Syariah dan UUS, syarat pemegang saham pengendali, dewan komisaris dan direksi, pembentukan DPS, tata kelola, manajemen risiko, penbinaan dan pengawasan, penyelesaian sengketa, dan sanksi. ${ }^{16}$

\footnotetext{
${ }^{16}$ Pasal 5,6, 23, 34-40, 50-52, 56-66 UU Perbankan Syariah
} 
$160 \mid$ Asy-Syari'ah Vol. 20 No. 2, Desember 2018

Keempat, asas Al-Bir wa al-Taqwa, asas ini yang mewadahi seluruh asas muamalah. Artinya segala asas dalam lingkup fiqih muamalah dilandasi dan diarahkan untuk Al-Bir wa al-Taqwa. Al-bir artinya kebajikan dan berimbang atau proporsional maksudnya keadilan atau perilaku yang baik sedangkan al-taqwa berarti: takut; hati-hati; jalan lurus; dan meninggalkan yang tidak berguna; melindungi dan menjaga diri dari murka Allah SWT. Aplikasi asas Al-Bir wa al-Taqwa dalam UU Perbankan Syariah adalah Pasal 26 tentang kegiatan usaha dan/atau produk dan jasa syariah, wajib tunduk kepada Prinsip Syariah.

\section{Simpulan}

Berdasarkan pembahasan di atas, maka dapat disimpulkan beberapa hal berikut ini: Prinsip-prinsip Syariah dalam Undang-undang Perbankan Syariah adalah dapat ditemukan pada Pasal 1 ayat (13), (20), (21), (22), (23), (24), (25), dan (28); Penjelasan Pasal 3, Pasal 5 ayat (4); Pasal 19 ayat (1) huruf a, b, c, d, e, f, g, dan i, Pasal 19 ayat (2) huruf a, b, c, d, e, f, g, dan i,Pasal 21, pertimbangan huruf (a), dan frase "Dengan Rahmat Tuhan Yang Maha Esa" di awal Undang-undang Perbankan Syariah. Implementasi Asasasas Hukum Ekonomi Syariah dalam Undang-undan Perbankan Syariah adalah dapat ditemukan pada Pasal 1 ayat (2), (8), (16), (21), (22), (23), (24), (25), (26), (27), Pasal 2, Pasal 4, Pasal 19, Pasal 26, dan Pasal 40 ayat (1) Undang-undang Perbankan Syariah.

\section{Daftar Pustaka}

\section{Buku}

Abd. Hakim, Atang. 2011. Fiqih Perbankan Syariah: Transformasi Fiqih Muamalah Ke dalam Peraturan Perundang-undangan, Bandung : Refika Aditama.

Algaoud, Latifa M. dan Mervyn K. Lewis. 2005. Perbankan Syariah: Prinsip, Praktik, Prospek, Jakarta : Serambi.

Ali, Masyhud. 2002. Restrukturisasi Perbankan \& Dunia Usaha: Pelosok Gelap di Balik Krisis dan Pertikaian Politik, Jakarta : Gramedia.

Antonio, Muhammad Syafi'i. 2005. Bank Syariah: Dari Teori Ke Praktik, Jakarta : Tazkia Cendekia.

Djamil, Fathurrahman. Tt. Hukum Ekonomi Islam: Sejarah, Teori, dan Konsep, Jakarta : Sinar Grafika

Hamid, Arifin. 2007. Hukum Ekonomi Islam (EkonomiSyariah)Dilndonesia. Bogor : Ghalia Indonesia,

Hartono, CFG Sunaryati. 1988. Hukum Ekonomi Pembangunan Nasional. Bandung : Bina Cipta.

Imaniyati, Neni Sri. 2013. Perbankan Syariah dalam Persfektif Ilmu Ekonomi, Bandung: Mandar Maju.

Janwari, Yadi. 2016. Pemikiran Ekonomi Islam, Bandung. Rosda. 

2017. Peradaban Ekonomi Islam, Bandung : Rosda.

Karim, Adiwarman. 2004. Bank Islam: Analisis Fiqih dan Keuangan, Edisi Ketiga. Jakarta : PT. RajaGrafindo Persada.

2016.

-, Sejarah Pemikiran Ekonomi Islam, PT. RajaGafindo Persada, Jakarta,

Manan, Abdul. 2009. Aspek Hukum dalam Penyelenggaraan Investasi di Pasar Modal Syariah di Indonesia, Jakarta : Kencana.

Manan, M.A. 1992. Ekonomi Islam: Antara Teori dan Praktik, Jakarta : Intermasa.

Mardani. 2015. Hukum Sistem Ekonomi Islam, Jakarta : PT. RajaGafindo Persada.

Praja, Juhaya S. 2012. Ekonomi Syariah, Bandung : Pustaka Setia.

Schultz, Erik Trolle-. 1986. How the First Islamic Banking was Established in Europe dalam

Butterworths Editorialstaff, London : Islamic Banking and Finance.

Shobuni, Muhammad Ali as-. Tt. Tafsir Ayat Ahkam, Jilid1, Beirut : Dar al-Fikr.

Sjahdeini, Sutan Remy. 1999. Perbankan Islam: dan Kedudukannya dala Tata Hukum Perbankan Indonesia, Jakarta : Grafiti.

Soekanto, Soejono. 1986. Pengantar Penelitian Hukum, Jakarta : Universitas Indonesia.

Soekanto, Soerjono dan Sri Mamudji. 1985. Penelitian Hukum Normatif suatu tinjauan singkat, Jakart : Rajawali Pers.

Soemitro, Ronny Hanitijo. 1994. Metodologi Penelitian Hukum dan Jurimetri, Jakart : Ghalia Indonesia.

Sudarsono, Heri. 2005. Bank dan Lembaga Keuangan Syariah Deskripsi dan Ilustrasi, Yogyakarta : Ekonosia.

Suhendi, Hendi. 2001. Fiqih Muamalah, Jakarta : PT Raja Grafindo Persada.

Syafei, Rachmat. 2001. Fiqih Muamalah, Bandung : Pustaka Setia.

Tritanta, Agus. 2012. Hukum Ekonomi Islam (Dari Politik hukum Ekonomi Islam Sampai Pranata Ekonomi Syariah). Yogyakarta : FH UII Press.

Wirdayaningsih. Tt. Bank dan Asuransi Islam Di Indonesia, Jakarta : Prenada Media.

\section{Peraturan Perundang-undangan}

Undang-undang Nomor 7 Tahun 1992 tentang Perbankan

Undang-undang Nomor 10 Tahun 1998 tentang Perubahan Atas Undang-undang Nomor

7 Tahun 1992 tentang Perbankan

Undang-undang Nomor 21 Tahun 2008 tentang Perbankan Syariah 
162 | Asy-Syari'ah Vol. 20 No. 2, Desember 2018 